\title{
EXCAVATIONS IN NAKUM STRUCTURE 99: NEW DATA ON PROTOCLASSIC RITUALS AND PRECOLUMBIAN MAYA BEEKEEPING
}

\author{
JaRostaW ŹratKA \\ WIEStaW KOSZKUL \\ KATARZYNA RADNICKA \\ Jagiellonian University, Cracow \\ Laura Elena Sotelo Santos \\ Universidad Nacional Autónoma de México \\ Bernard Hermes \\ Instituto de Antropología e Historia de Guatemala
}

\begin{abstract}
Structure 99, located on top of a large platform occupies a major and prominent part of the North Group complex of the Maya site of Nakum situated in the north-eastern area of Guatemala. Archaeological excavations realized in this structure during a few field seasons have revealed interesting data about the very last moment of Nakum's development during the Terminal Classic period (AD 800900/950). It also revealed important traces of architectural and ritual activities from the still enigmatic Protoclassic phase (ca. 100 BC-AD 300). Scattered ceramics, stone tools and human bones found on top of Structure 99 - associated with the final hours of its occupation as well as Protoclassic offerings discovered in the lowest layers of this construction, including intriguing clay heads and jade pendants - are evidence of important ceremonial activities and beliefs that everything in the world is alive. By caching or destroying artifacts within the building, it is symbolically animated or killed by the Maya. This paper presents the results of the most important research conducted in Structure 99 that contributes to our knowledge on the ritual and architectural activities of two crucial periods in the history of Nakum: the Protoclassic and Terminal Classic. Among numerous findings described in this article, there is one that merits special attention. It is a cylindrical ceramic artifact lately identified as a beehive, providing a new perspective on beekeeping by the ancient Maya. The artifact is dated to the Protoclassic phase and is one of the oldest beehives discovered in pre-Columbian Mesoamerica.
\end{abstract}

KeYwords: Maya culture, Terminal Classic, Protoclassic, termination rituals, beekeeping, beehive.

Resumen: El Edificio 99, ubicado en la cima de una gran plataforma ocupó un lugar prominente en el complejo denominado el Grupo Norte del sitio maya de Nakum, en el noreste de Guatemala. Durante los recientes trabajos de campo que se llevaron a cabo en esta parte del sitio, se han revelado algunos datos interesantes sobre el último momento del florecimiento de Nakum durante el Clásico Terminal (800- 
900/950 d.C.). Además se hallaron vestigios importantes de la actividad constructiva y ritual perteneciente a la enigmática fase Protoclásica (ca. 100 a.C.-300 d.C.). Tanto la cerámica dispersa, las herramientas de piedra y los huesos humanos encontrados en la cima del Edificio 99 con fecha del Clásico Terminal, así como las ofrendas colocadas debajo de esta construcción, que incluyen intrigantes cabezas de barro y colgantes de jade, son evidencia de actividades ceremoniales muy importantes y creencias religiosas según las cuales cada cosa del mundo está viva. Al esconder o destruir diversos artefactos en el edificio, los mayas animan o matan simbólicamente esta construcción. Entre los numerosos hallazgos efectuados en el área del Edificio 99, hay uno que merece una atención especial. Es un artefacto cilíndrico de cerámica, identificado en última instancia como una colmena, que proporciona una nueva perspectiva sobre la apicultura de los antiguos mayas. La pieza en cuestión data de la fase Protoclásica y constituye una de las colmenas más antiguas descubiertas en toda Mesoamerica.

Palabras clave: cultura maya, Clásico Terminal, Protoclásico, ritos de terminación, apicultura, colmena.

RECEPCIÓN: 4 de junio de 2014.

ACEPTACIÓN: 12 de agosto de 2014. 


\title{
EXCAVATIONS IN NAKUM STRUCTURE 99: NEW DATA ON PROTOCLASSIC RITUALS AND PRECOLUMBIAN MAYA BEEKEEPING
}

\author{
JAROStAW ŹratKa \\ WIEStAW KOSZKUL \\ KATARZYNA RADNICKA \\ Jagiellonian University, Cracow \\ Laura Elena Sotelo Santos \\ Universidad Nacional Autónoma de México \\ Bernard Hermes \\ Instituto de Antropología e Historia de Guatemala
}

\section{Introduction}

Recent research at the Maya site of Nakum, (located in the north-eastern part of the Petén Department of Guatemala; figure 1) yielded interesting results, enriching our knowledge of how this site developed in a wider cultural and geographic context. In particular, Structure 99 from Nakum was the subject of intensive excavations during which we were able to document several stages of its architectural growth and discover two interesting offerings dated to the still poorly known Protoclassic phase. We also found important vestiges of Terminal Classic occupation. As we will show, excavations conducted in Structure 99 contribute to a deeper understanding of several issues in Maya archaeology, especially pre-Columbian beekeeping, Late Preclassic-Early Classic transition and rituals of the Protoclassic phase.

\section{The site of Nakum}

Structure 99 was excavated by the Nakum Archaeological Project from the Institute of Archaeology of the Jagiellonian University. Investigations were realized thanks to permission granted by the Guatemalan Institute of Anthropology and History (IDAEH) and Ministry of Culture and Sports of Guatemala. The history of investigations at this site goes back to the beginning of the $20^{\text {th }}$ century when Nakum was discovered by a French count, Maurice de Perigny in 1905 (Perigny, 1908). Perigny came back to Nakum in 1910, when he spent around 6 weeks at the ruins, clearing the Maya buildings of overgrown vegetation in order to take 


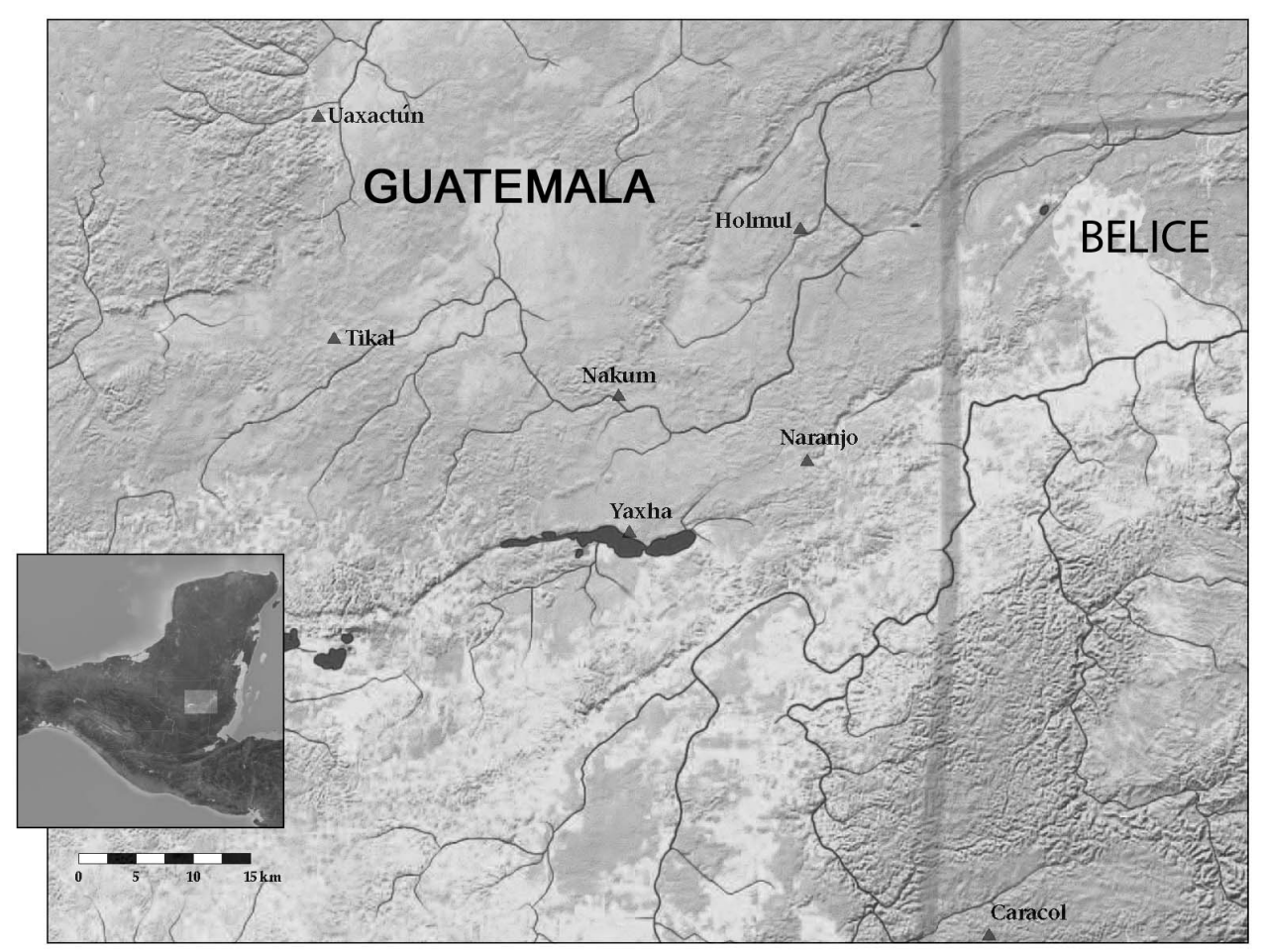

FIGURE 1. Map of the northeastern part of Guatemala showing the location of Nakum and other neighboring sites (map courtesy of Precolumbia Mesoweb Press).

panoramic size pictures. Further investigation was carried out during two short expeditions organized by the Peabody Museum of Harvard University and directed by Alfred M. Tozzer. Tozzer accompanied by Raymond E. Merwin prepared plans of the most important structures. They have also produced a map of the central part of Nakum (Tozzer, 1913). The Peabody Museum also carried out some minor excavations. Subsequently, the Carnegie Institution of Washington showed some interest in the site, sending Sylvanus Morley in 1915. Morley returned to Nakum twice in 1921, and once in 1922. He was followed in 1923 by the next Carnegie expedition led by Oliver Ricketson and W.A. Love who conducted latitude and longitude measurements. In 1937 and 1938, Morley published his famous work, "The Inscriptions of Petén" in which he included descriptions, drawings and photographs of carved monuments at Nakum as well as an updated plan of the site based on Merwin's Map (Morley, 1937-38: vol. II: 7-21; vol. V: part 1, plates 13, 86; part 2, plate 194). The site lay abandoned during the ensuing decades. However, in the 1960's and 1970's it was heavily damaged and ransacked by looters and people seeking precious wood species (Quintana and Wurster, 2002: 244). 
Scientific attention turned to Nakum briefly towards the early to mid 1970's when in 1970, the Guatemalan archaeologist Miguel Orrego and a Los Angeles businessman, Ovid Kosovsky visited the site (Hellmuth, 1975: 270). An American archaeologist Nicholas Hellmuth, who at that time was working $12 \mathrm{~km}$ further to the south at the site of Yaxha, came to Nakum, first in 1971 with a NBC TV crew to make a movie, and then in June 1973, when Hellmuth spent 3 or 4 days at Nakum. The latter visit resulted in some corrections of the existing maps and a further description of the ruins (Hellmuth, 1975, 1978: 93-95, 1992). In 1989, The Institute of Anthropology and History of Guatemala (IDAEH) started a program of protection of several threatened buildings located in the centre of Nakum in the frame of the Tikal National Project. Archaeological investigations carried out by the IDAEH were initiated in 1994 with excavations and restoration of the most deteriorated monumental structures located at the core of the site (Calderón et al., 2008; Hermes, 2002; Hermes and Calderón, 2003; Hermes and Źrałka, 2008; Noriega, 1999; Noriega and Hermes, 2000; Noriega and Quintana, 2002; Noriega et al., 2008). Between 2001 and 2003, investigations were also realized at the periphery of the site leading to the discovery of thirty six habitation compounds (Hermes et. al. 2005, 2006). Triángulo Project research at Nakum continued till 2008. Archaeological work at the site was first supervised by Bernard Hermes and then, since 2002 by Zoila Calderón. Restoration and consolidation actions were directed by Raul Noriega and Breitner González. In 2006 a new project from the Jagiellonian University in Cracow, Poland started investigations at Nakum. It focused on excavations of unexplored buildings and complexes with the aim of gaining a deeper understanding of the development of the site, especially during the important periods in Nakum's history; namely, the Protoclassic, Early Classic and Terminal Classic periods.

Nakum has a north-south orientation, approximately $1000 \mathrm{~m}$ long; with an east-west axis that does not exceed 500 meters. Its core area is divided into two major sectors (North and South) connected by the Perigny Causeway, which is $250 \mathrm{~m}$ long (figure 2). Structure 99, that is the main subject of this article, is situated at the northern extreme of the North Sector. The latter sector consists of a spacious North Plaza around which there are several low platforms originally supporting perishable constructions and by a temple structure (Structure X). The northern part of the plaza is delimited by the North Group or the North Acropolis complex. The East Group - a massive platform topped by 14 buildings - occupies the south-eastern corner of the North Plaza, while a small complex of West Group is situated in south-western perimeters of the Northern Sector.

\section{Structure 99 and Terminal Classic occupation}

One of the major concerns of our project was the North Group, the largest complex of the North Sector. The North Group consists of a large platform which 
A

B

C

D

E

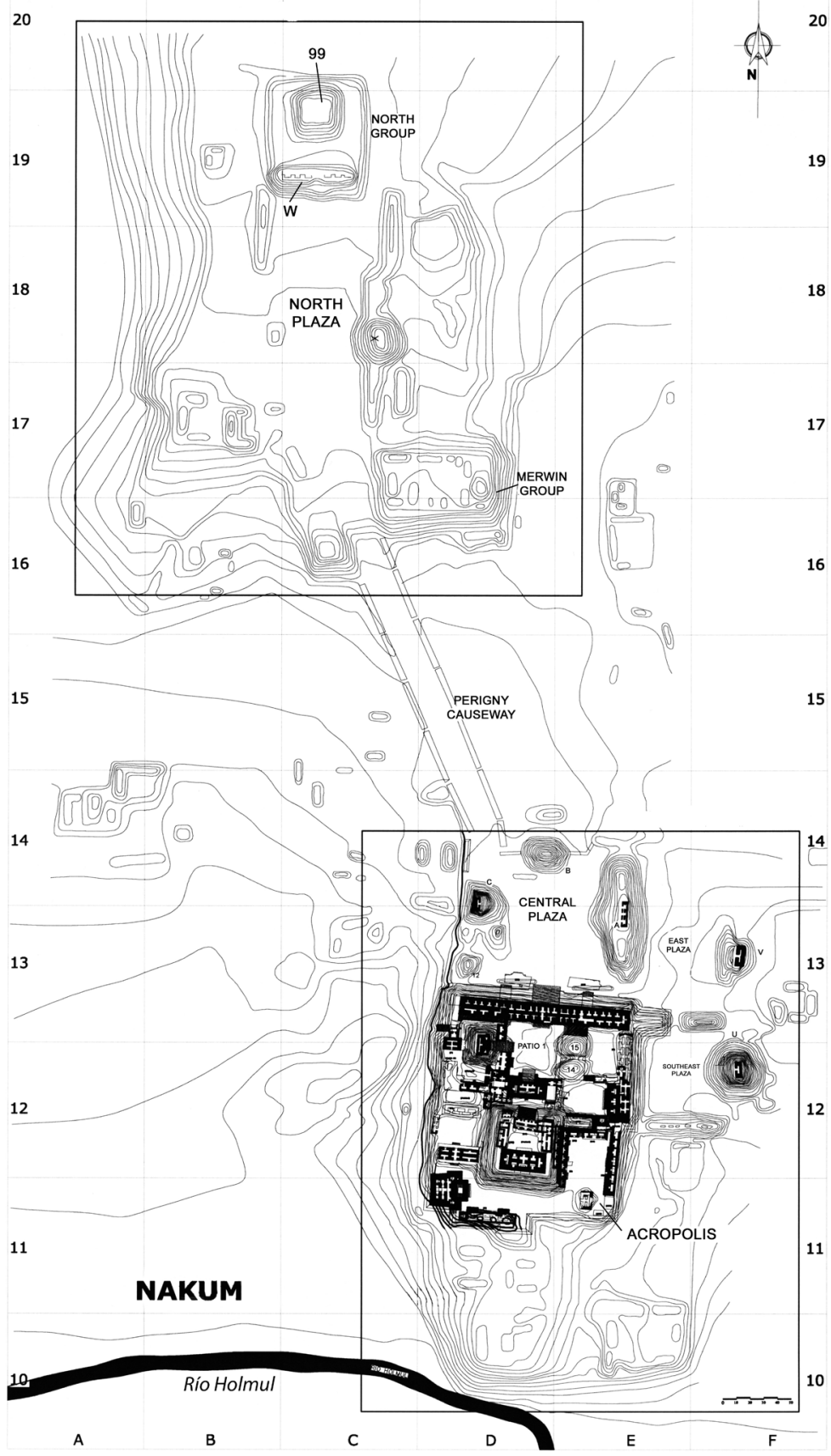

18

17

16

15

FigURE 2. Map of Nakum showing two principal sectors and a causeway (Proyecto Triángulo/DECORSIAP, IDAEH). 
is topped by one long palace-like construction with fourteen or so chambers (Structure W), one low platform that is almost flat at the top (Structure 99) and at least two low mounds which, most probably are the remains of residential constructions (figure 3). All the above-mentioned structures surround a small courtyard. Structure 99 was excavated by means of two tunnels, several trenches, one large test-pit and extensive excavations (consisting of 37 excavation units, most of which measured $2 \times 2 \mathrm{~m}$ ) realized at its upper, plain part. At the top of Structure 99, excavations revealed the existence of three superstructures

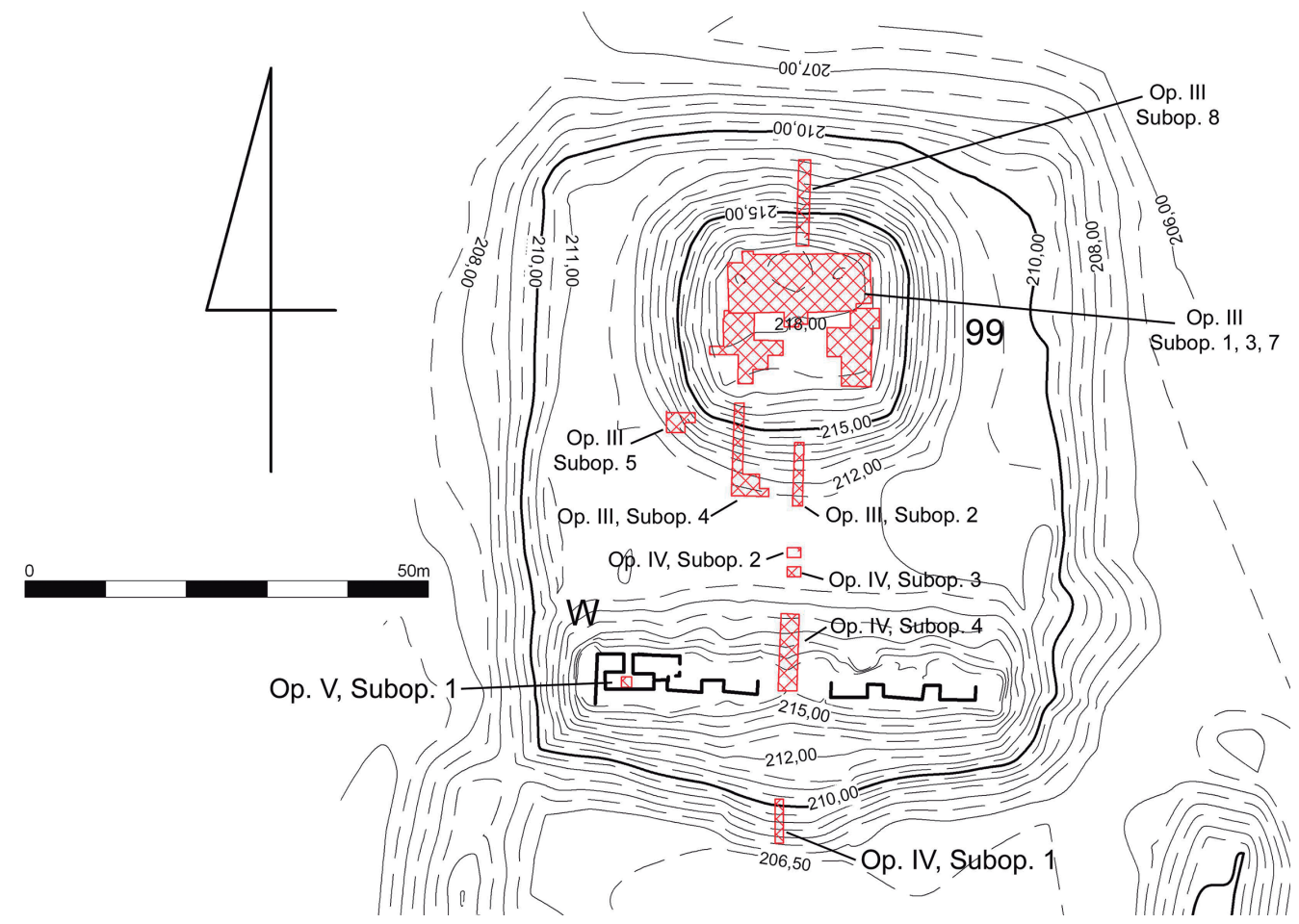

FIGURE 3. Map of the North Group of Nakum showing all excavation units realized by the Nakum Archaeological Project (map by Michał Sip).

(99A, 99B and 99C) forming a triadic pattern and dated to the Terminal Classic period (figures 4 and 5). The largest of them was Structure 99A. It consists of five rooms and measured $c a .16 \mathrm{~m}(\mathrm{E}-\mathrm{W})$ by $9.20 \mathrm{~m}(\mathrm{~N}-\mathrm{S})$. Its principal access was from the southern side where three openings, each about $1.40 \mathrm{~m}$ wide were detected. The walls were preserved up to a height of $0.30 / 0.50 \mathrm{~m}$ and it appears that its lower parts were constructed of masonry while its upper section and roof were made of perishable materials (figure 5), similar to many other Maya structures (e.g. at Aguateca; see Inomata et al., 2002). 


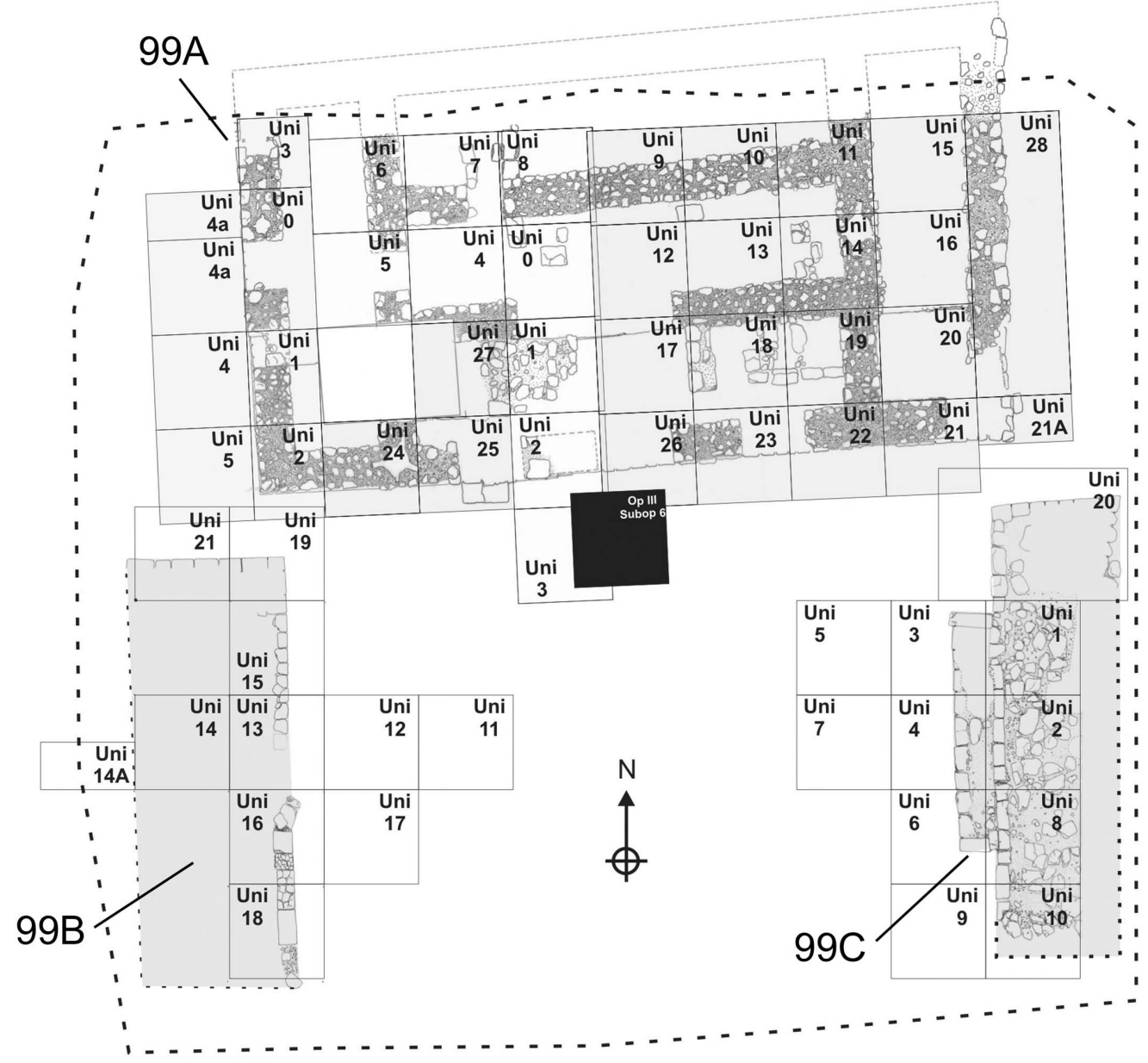

FiguRE 4. Map of excavations conducted in the upper part of Structure 99 with location of three superstructures discovered on its top (Structures 99A, 99B and 99C), Terminal Classic period. 


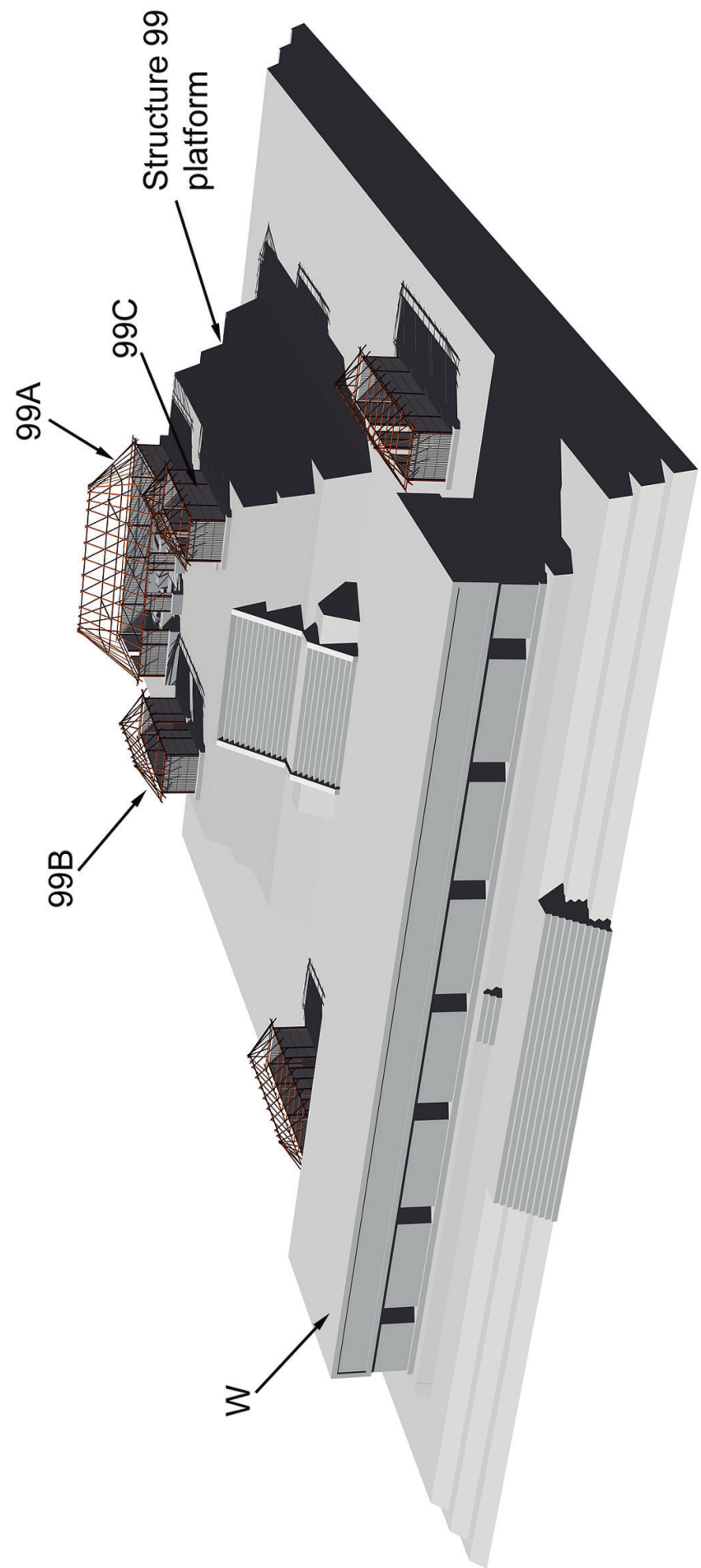

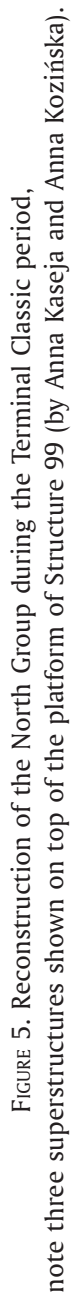


The floor of Structure 99A was scattered with numerous artefacts (figure 6). The context of this find is reminiscent of the so-called termination rituals documented at various Maya sites that were conducted prior to the abandonment of the structure. We currently know that the so-called "termination rituals" were performed for a variety of reasons during different periods of Maya history. They can also be interpreted in many different ways (Garber, 1983; Mock, 1998; Freidel et al., 1998; Inomata, 2003; Straight and Marken, 2006; Farr and Arroyave, 2007). It is usually construed as a special celebration commemorating the termination of the use of a residence or temple. This could happen under many different circumstances: $a$ ) during the ceremonial closing of a building used by a deceased king and subsequently remodeled and occupied by the replacing lineage; $b$ ) before abandoning the structure or even a town or $c$ ) for a very special reason like the end of the calendar cycle (Walker, 1998). Other such findings from the Maya area represent rituals performed as an act of desecration (Stanton et al., 2008, Brady and Colas, 2005). In this case the invaders were emphasizing the defeat of their enemy by violating his residence. According to this interpretation, the termination ritual should be treated as the symbolic killing of the structure and peacefully releasing its soul (Inomata et al., 2001, Ponciano and Pinto, 2007).
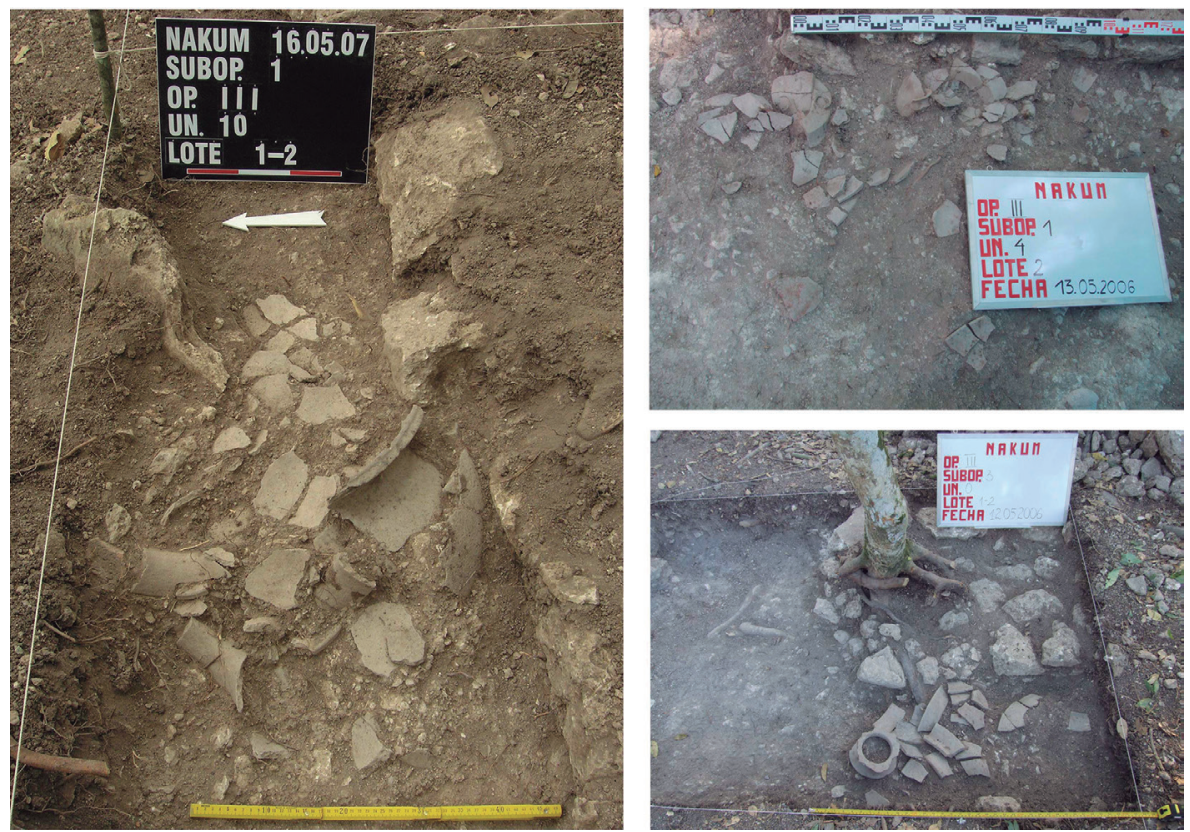

FIGURE 6. Photographs showing scattered ceramics found on the floor of Structure 99A, a possible vestige of termination ritual (photographs by Jarosław Źrałka). 
Offerings from termination rituals were generally not placed in cache-like spaces but rather on the floors of rooms; they might have also included former dedication deposits that were ritually destroyed. The termination ritual was meant to kill the structure or room by pulling its heart out. Pottery is usually intentionally scattered around and it is interesting that the vessels are only partially reconstructable (Stross, 1998). What is even more interesting is that ritual deposits of this type never contain animal bones (only as carved artifacts), while human bones are sometimes present (in spite of this, the structure usually cannot be considered a burial (Farr and Arroyave, 2007; Inomata et al., 2001). In some instances, all area of the ritual was found covered with a layer of white marl or clay (Wagner, 2002; Freidel et al., 1998). In other cases there is no evidence of long-term exposition of offered objects and space (structure or room). Instead, walls or vaults seem to have collapsed shortly after the deposition of the objects integral to the termination rituals or rather have been intentionally pulled down to cover and seal the place (Stross, 1998; Stanton et al., 2008).

Remains of presumed termination rituals on Superstructure 99A consist of two big concentrations of pottery sherds, some broken flint axes and fragments of clay figurines and human bones. Pottery was found in a rear and central room, placed close to the walls. All sherds were highly eroded, but we can classify them as fragments of short-neck jars or plates with hollow supports or one-cylinder vessels, etc. The majority of these artefacts can be dated to the Terminal Classic, although Late Preclassic ceramics were also found. Using the fragments found, it was not possible to reconstruct a whole vessel. In addition, human bones were found very close to the artifacts' concentration in the central room (or Room 2), next to the remains of a bench. Most probably they represent an individual who was left unburied or only partly covered by soil. Similar examples of partly exposed burials were found at several Maya sites in the Terminal Classic context (see Harrison, 1999: 193, 195, 197; Helmke 2006: 176, 182-183; Valdés and Fahsen, 2004:153; Vidal and Valdés, 2007: 18).

It must be noted that the lack of typical features like layers of white clay, large amounts of pottery scattered in different rooms of the building (especially in passageways), traces of fire etc. make it difficult to say conclusively that a termination ritual had taken place. It is possible that the pottery was part of a midden left by the final inhabitants and that the human skeleton belongs to an individual who died there or was killed and abandoned without a funeral (comp. Stanton et al., 2008).

\section{Preclassic antecedents}

The excavation of two tunnels at the base of Structure 99 as well as one test-pit nearly $9 \mathrm{~m}$ deep opened at its top, along with investigations conducted in the North Group platform revealed that the first major versions of this construction 
are associated with the final part of the Late Preclassic period or Protoclassic phase (figure 7). In its first version (denominated 99 Sub-1), Structure 99 was a single chamber building located on a low platform with a stairway on its southern face. The building was between 7 and $8 \mathrm{~m}$ long (N-S), but its width is unknown. During excavation, an interesting offering deposited at the base of the stairway and on the main axis of Structure 99 Sub-1 was discovered. It was placed on the floor (Floor 4) of a small cist or cript delimited by stone blocks and covered by two large stone slabs. The area of the cist was ca. 0.85 (E-W) x 0.80/0.90 (N-S). Denominated as Offering 9, it consisted of nine clay heads placed in a circle; more or less in the middle of this circle were two jade jewels: a pendant with a monkey head representation and a spherical bead (figure 8). Furthermore, on the eastern side of the cist was a ceramic artifact - a cylindrical tube with two covers. It is not clear if the objects deposited as Offering 9 had any symbolism. Of the nine heads, only four or five were in satisfactory condition. Very similar heads made of unfired clay have been found at Tikal in caches or problematical deposits (Moholy-Nagy with Coe, 2008: figs. 220 and 221) usually in a Classic period context, although several small clay figurine fragments of Preclassic date have been also discovered. The number of heads (nine) in the case of Nakum may be connected to the Nine Lords of the Night known from Mesoamerican calendars. The best preserved head represents that of an aged man. Another depicts a god with a long nose and a small serpent-like element sticking out of the mouth. The latter artifact is very similar to the Tikal examples which represent deities with zoomorphic features, some of whom may be identified as depictions of Sak huunal, Chaak, or K'awiil. Moreover, Offering 9 contained a stingray spine with a sharp, notched edge, which the Maya used for ritual bloodletting. The spine was ritually broken and placed on clay heads. It is very likely that the deposition of Offering 9 was accompanied by ritual bloodletting, followed by the ritual breaking of the stingray spine.

\section{Ancient Maya beehive}

A ceramic tube with two covers found in Offering 9 merits special attention (figure 9). It is $30.7 \mathrm{~cm}$ high, has a maximum diameter of $18 \mathrm{~cm}$ with a hole $3 \mathrm{~cm}$ in diameter at the middle. Its walls are covered with striated designs. In addition, it has two ceramic covers at each end, with diameters of 16.7 and $17 \mathrm{~cm}$, respectively. This piece most probably represents the so-called Morfin Unslipped ceramic type while its covers are of the Zapote Striated type, typical for the Late Preclassic period.

Archaeological, ethnohistorical and ethnographic evidence from the Maya area indicate that the aforementioned artifact may be interpreted as a real or artificial beehive and as such, it could well be the oldest artifact of this type known not only from the Maya area, but from all of Mesoamerica. In the Northern Maya 


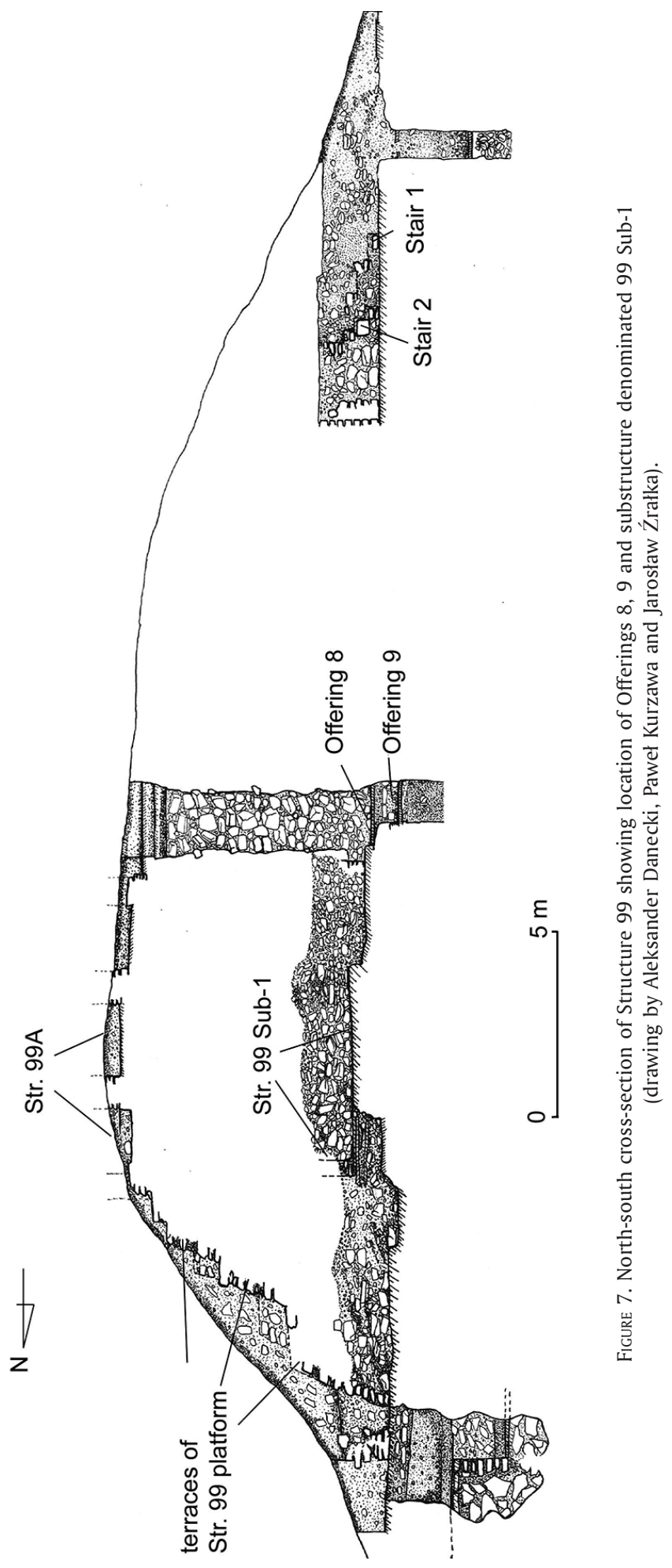



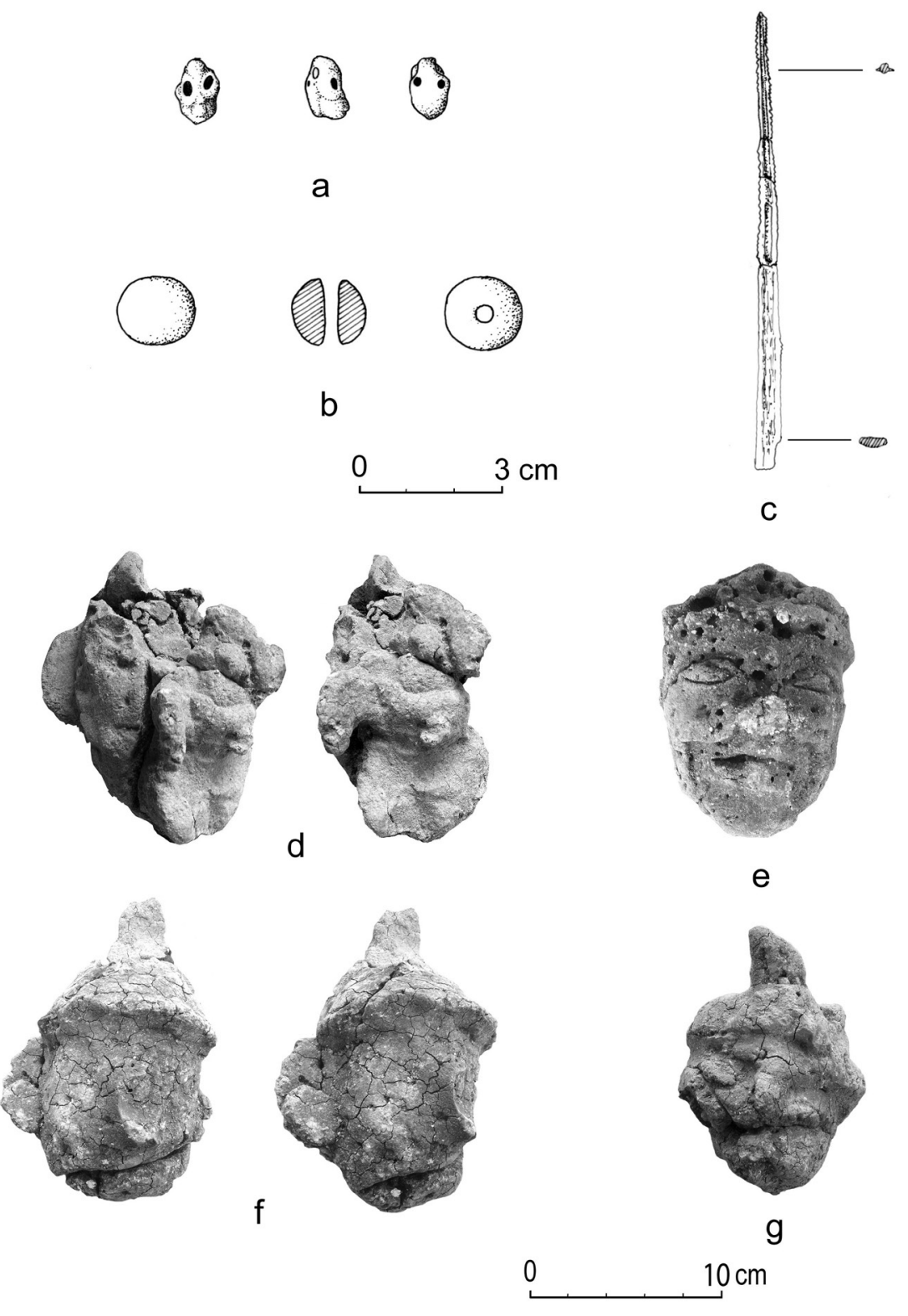

Figure 8. Several artefacts found in Offering 9: four of nine clay heads, stingray spine and jade sphere (drawing by Katarzyna Radnicka, photograph by Jarosław Źrałka). 

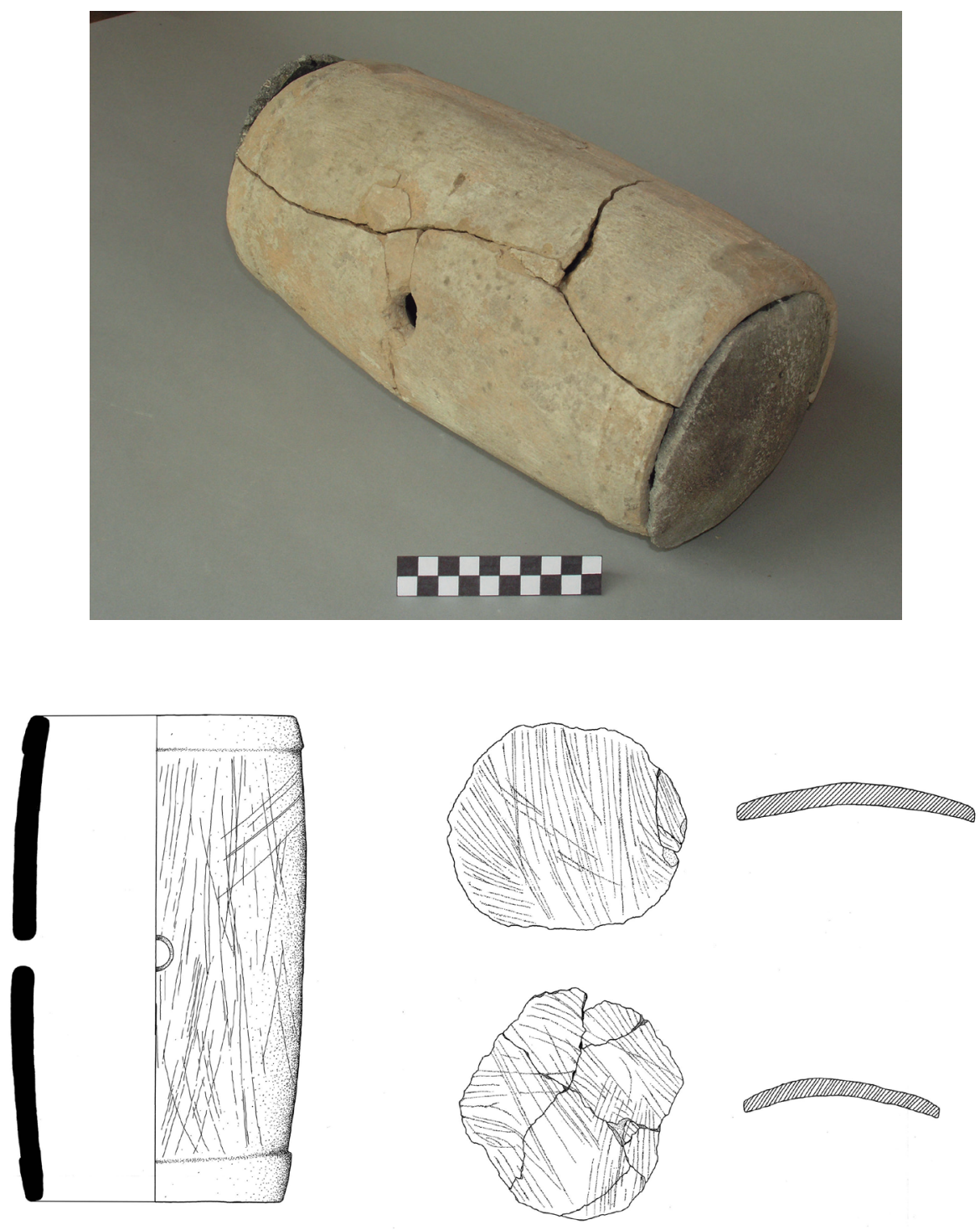

Figure 9. Photograph and drawing of a beehive found in Offering 9 (drawing by Katarzyna Radnicka, photograph by Robert Słaboński). 
Lowlands, especially in the eastern coast of the Yucatán Península, there is evidence of large-scale intensive farming of stingless bees (Meliponinae) from the pre-Columbian era (Nárez, 1988) up to present times. Due to its shape and other physical characteristics, the Nakum ceramic tube appears to be very similar to the cylinders of clay that are part of the decoration of censers of the so-called Chen Mul type. These censers bear representations of horizontal log hives in which the Maya have beenkeeping native bees for more than 500 years. The modern Yucatec Maya name these objects is jobón. They are made of wooden logs and have two end closures on both of their ends made of the same material or stone (figure 10). Jobón also bear a central hole (through which bees can enter the log) and it is stored in a horizontal position. By removing the end closures that seal jobón at both ends, one can easily collect the honey and wax. Moreover, when the colony is ripe, it can be easily divided and moved to the new jobón by means of the hive openings. The shape and material from which jobón is made is not coincidental: the structure of the jobón imitates the natural habitat of bees such as trees bearing holes.

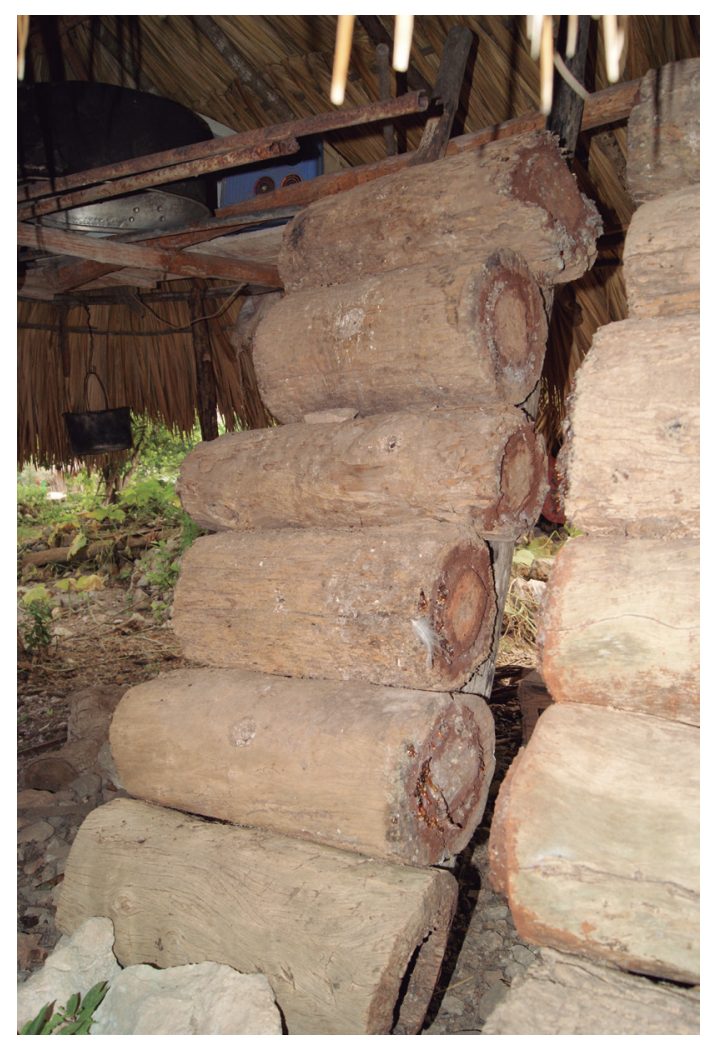

FIGURE 10. Maya stingless beehives (jobón) of Yucatan State. Photograph by Laura Elena Sotelo Santos. 
Today, very few Maya communities have apiaries of the Melipona beecheii (Bennet) species - stingless bees that are called Ko'olel Kab or Xunaan Kab (lady bee), which the modern Maya consider sacred. It is possible that the traditional way of keeping this species was cultivating them in the above-described jobón or log hive. Jobón from various parts of Yucatán have very similar characteristics: their average length is $50-60 \mathrm{~cm}$, have a diameter of $30 \mathrm{~cm}$ and their walls are usually more than $4 \mathrm{~cm}$ thick while the central hole is less than $1.5 \mathrm{~cm}$ in diameter. Every jobón has two disc-shaped end closures with an average diameter of $18 \mathrm{~cm}$. The Maya horizontally stack the jobón on A-shaped wooden racks. Rows of these racks are positioned on an east-west axis and covered by a guano roof to protect them from sun and rain.

Detailed information on the cultivation of native bees can be found on the last ten pages of one of the Maya pre-Columbian codices (Tro-Cortesianus Codex, socalled Madrid Codex) (Sotelo, 2002). The latter source shows the importance that the Maya attached to the farming of stingless bees; there are sections in the codex covering various aspects of beekeeping such as a description of animals that preyed on honey-storing bees, the harvesting and collection of honey, the division of beehives and various rituals related to apiaries. Interestingly, the importance of beekeeping for the ancient Maya is seen in the fact that in the Tro-Cortesianus Codex the beehives are operated by deities. Besides accurate depictions of bees, the Tro-Cortesianus Codex also contains representations of the exterior and interior parts of the horizontal log hives. The exterior parts of the beehives are shown as rectangles having the color of honey with possible end closures depicted as white, vertical strips or bands on both ends of the hives. The Tro-Cortesianus Codex also contains numerous depictions of the interior parts of the hives, probably with the intention of showing their content. The interiors are depicted as rectangles with a white background on which schemes of egg-shaped pots (where the bees store pollen and honey) made of beeswax are depicted (figure 11).

As far as the archaeological analogies to the Nakum piece are concerned, two ceramic examples are especially important. Both are censers representing smallscale beehives. Both of them come from the Isla de Cozumel, a very important centre for the production of honey and wax in the Late Postclassic period. This wealthy honey center was noted and recorded by the first Spaniards who came to the eastern coast of the Yucatán Península (Díaz del Castillo, 1968: Chapter VIII). One of these censers is now exhibited in the deities' showcase of the Museo Palacio Cantón in Mérida, Yucatán. This decorated censer has a representation of the so-called Diving God holding honeycomb cells (possibly of the Melipona beecheii species) in its hands (figure 12). Honeycomb cells come from the interior of beehives. They are removed and placed in other horizontal wooden hives in order to seed new colonies. On both sides of the deity, two pairs of small beehives are represented. This further supports the interpretation that the censer was an object strictly related to beekeeping. The hives from this artifact are well rendered and are depicted as overlapping, with a central hole and two stoppers at both ends. 


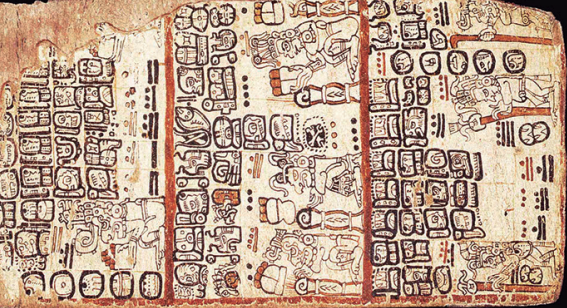

- T.

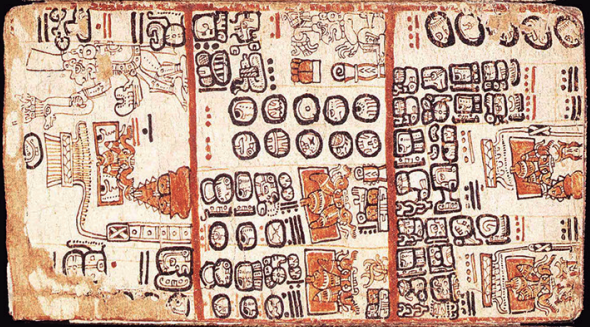

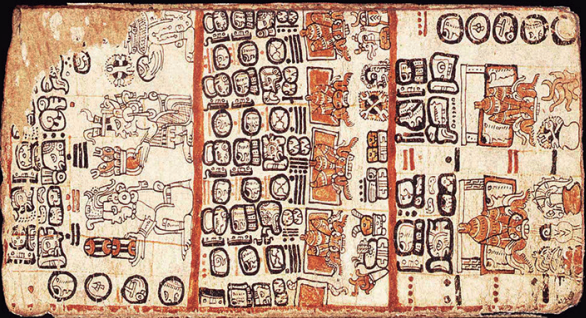
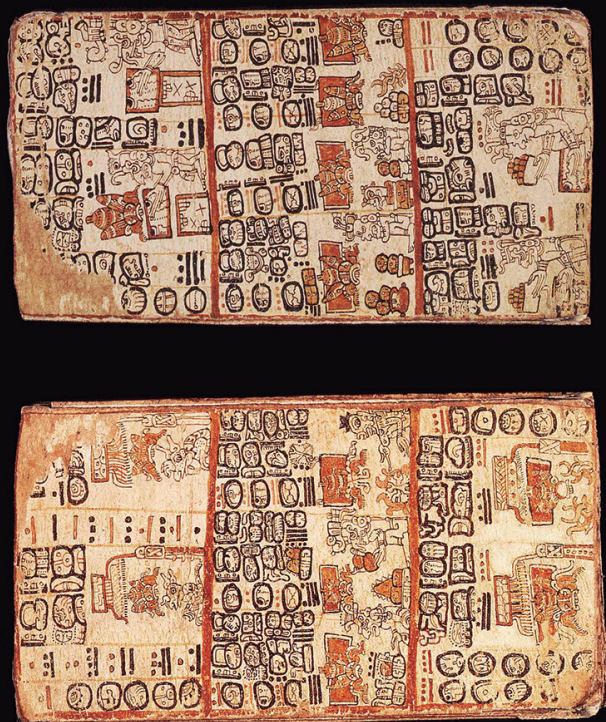
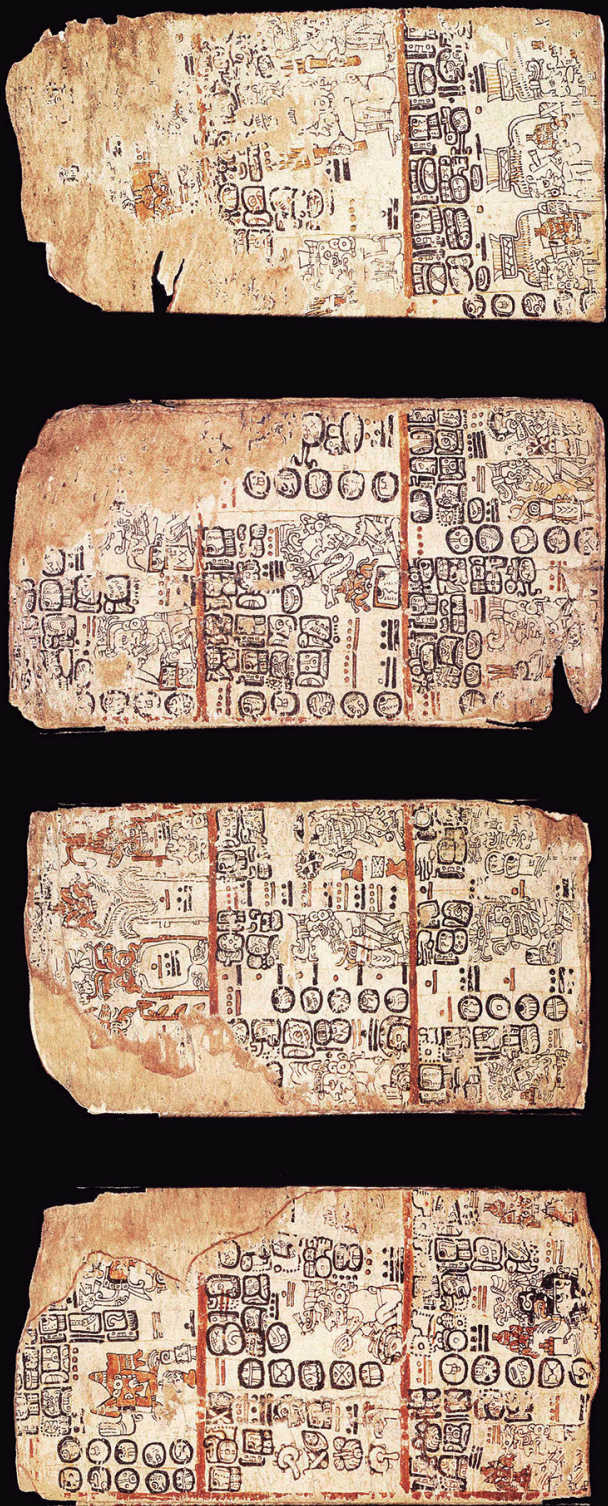

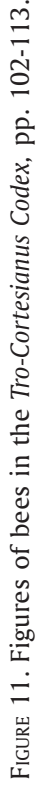

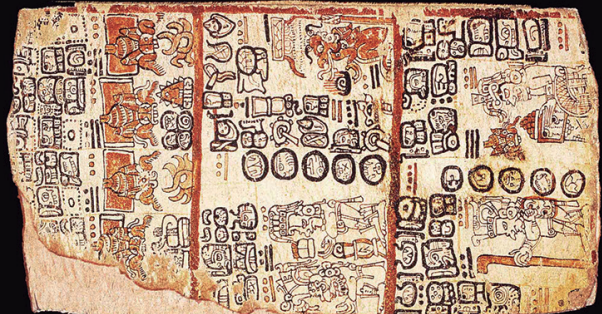



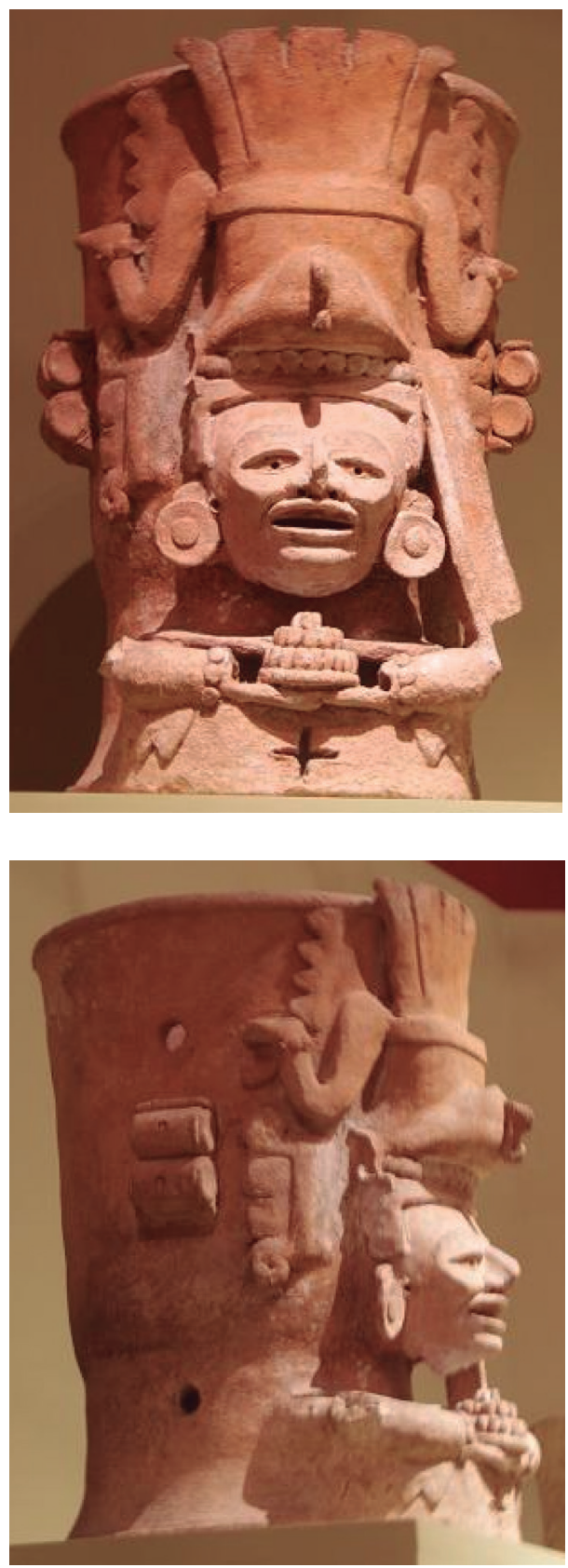

FIguRE 12. Censer of the Chen Mul Type, Diving God holding honeycomb cells in its hands. On both sides of the deity, two pairs of small beehives are represented. Mérida, Yucatán, México. Photograph by Laura Elena Sotelo Santos. 

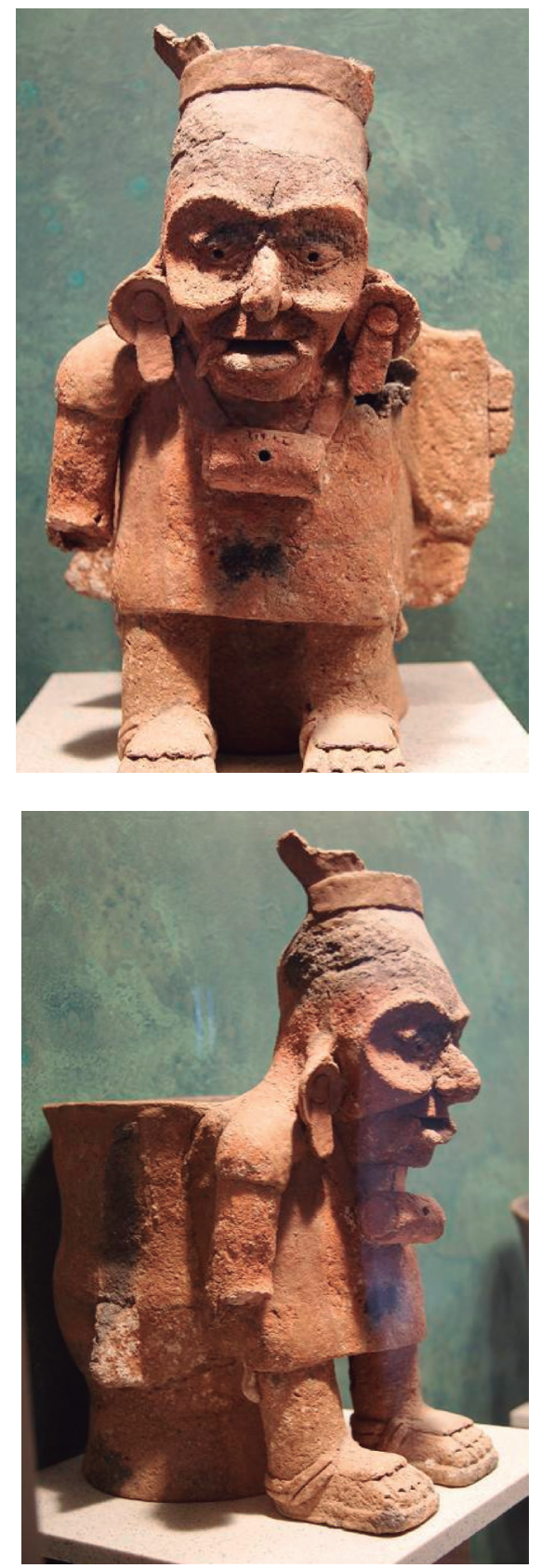

Figure 13. Censer of the Chen Mul Type, deity with necklace with a beehive. Maya Room at National Museum of Anthropology in México City. Photograph by Laura Elena Sotelo Santos. 
Another example of an object similar in form to the Nakum piece is exhibited at the Maya Room at the National Museum of Anthropology in México City. This too is a censer and its frontal part bears the representation of a deity. On its chest, the deity has a necklace with a beehive and it is worn in a horizontal position (figure 13).

All data presented above indicate that the form, proportions and other elements of the ceramic cylinder found in Offering 9 can be strictly related to the beekeeping of native stingless bees. The object may be a visual representation of a horizontal beehive or it might have been used as such by the pre-Columbian Maya. If our hypothesis is correct, the Nakum piece represents a real or symbolic beehive, making it the oldest in the Maya area and one of the oldest in all of Mesoamerica. Not only does this finding prove the antiquity of beekeeping in Mesoamerica, but it also points to the sacred function that the Maya attributed to at least some species of native bees.

\section{Offering 8 and stone spheres}

At some later time during the Protoclassic phase, Structure 99 Sub-1 was sealed. Above it a new construction, a platform nearly $6 \mathrm{~m}$ high was built. However, before the Maya sealed Structure 99 Sub-1, another offering (no. 8) was placed just above Offering 9 . Subsequently, they build a $6 \mathrm{~m}$ high platform which most probably was plain at the top. Both Offering 8 and the platform were dated ceramically to the Protoclassic phase.

Offering 8 contained four ceramic discs representing various ceramic types (Polvero Black, Paila Unslipped and Zapote Striated) (figure 14). Discs were in fact reworked sherds made from large bowls or jars; some of them had concave cross-sections. In addition, Offering 8 included six tubular bone beads, one pyrite bead, one jade pendant with the representation of a monkey head, one pearl, two pendants made of conch shells and one mammal canine which was placed on one of ceramic discs. Also, a plate of Guacamallo Red/Orange placed in an upside down position was found. This plate covered a group of about 25 stone spheres or sphere-like elements as well as clods of unbaked clay. Similar stone spheres dating from this time period have been discovered in other offerings across the Maya area. Recently, as part of the offerings, many stone spheres were found placed inside vessels discovered by Takeshi Inomata at Ceibal. These spheres were found in a Protoclassic context (as at Nakum), in front and on the main axis of one of the excavated structures (Inomata et al. 2010). Other examples were recorded at K'axob (Harrison-Buck, 2004: 72 and fig. 4.2; McAnany and Ebersole, 2004: 321). In the case of Tikal, several similar but more oblong artifacts made of unidentified clayed material were found in Protoclassic Burial 85 (Moholy-Nagy with Coe, 2008: fig. 223a). This custom was very popular and widespread further to the south, in the Pacific coast and Highlands of Guatemala as well as in Chiapas (Schieber de Lavarreda, 2002). The exact function of the stone spheres is not 

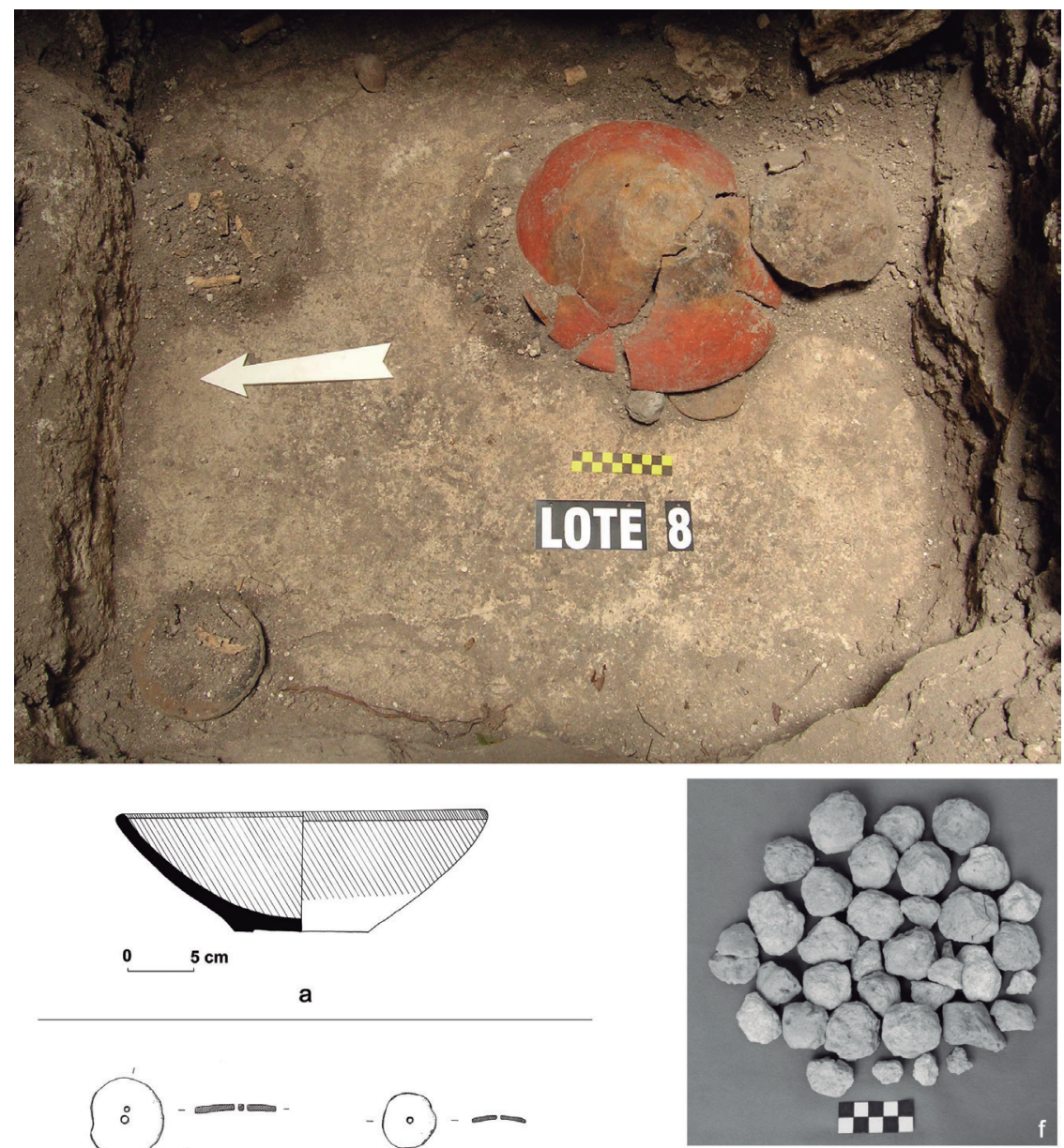

b

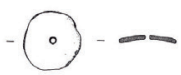

C

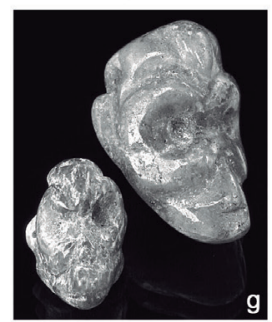

Figure 14. Photograph showing Nakum Offering 8 during excavations (up) along with drawings of all its artefacts, a) plate of Guacamayo Red/Orange type; b) ceramic disc of Paila Unslipped type [?] (PANC 017); c) ceramic disc of Polvero Black type (PANC 014); d) ceramic disc of Zapote Striated type (PANC 016); e) ceramic disc of Paila Unslipped type (PANC 015); f) stone spheres or sphere-like artefacts; $g$ ) jade pendants featuring monkey heads from Offerings 8 and 9. Drawing by Katarzyna Radnicka, photographs by Jarosław Źrałka and Robert Słaboński. 
clear. McAnany and Ebersole (2004: 321) suggest that they could have been used as a slingshot stones. Inomata et al. (2010: 40) enlists several theories explaining their function: a) they might have been used as slingshot stones; $b$ ) related to calendric calculations or divination rituals, or alternatively; $c$ ) symbolize tamales. They might even have been used to heat water. At K'axob, all such spheres save one example were found to be present in a ritual context, being part of a cache or a grave good. At Ceibal, such stones were also found in a similar, ritual context (as offerings). The Tikal examples come from an important burial, possibly that of a local dynasty founder. Some ethnographic data may indicate that such stone balls were associated with the ritual use of incensarios (Schieber de Lavarreda, 2002: 404-405). In fact, these artifacts are very similar to modeled balls of copal (see e.g. Tikal copal balls: Moholy-Nagy with Coe, 2008: fig. 246a) and might have had some connection to incense burning; maybe they were imitation of such copal balls. Although the exact function of the above-described artifacts is not well known, it seems that they were part of a common and widespread ritual and belief system that was typical for the Late Preclassic-Early Classic transition.

It is also interesting that in the case of both Offerings 8 and 9, jade pendants in the form of a monkey head were found. It is probably not coincidental that pendants showing the same animal were discovered here. They were most probably part of necklaces which were placed in the offerings. Monkeys in Mesoamerican art are usually associated with clowning, drunkenness, sexuality as well as dance and music. Monkeys were also connected to artisans and scribes since they were usually represented in the guise of these animals (Taube, 2004: 154; Stone and Zender, 2011: 197). Pendants in the form of monkeys appear from Preclassic times and according to Karl Taube (2004: 155), such objects may refer to such social functions as performance and entertainment.

The overall archaeological context of Offering 8 may indicate that it was a deposit marking the dedication of a new structure built above Str. 99 Sub-1. One

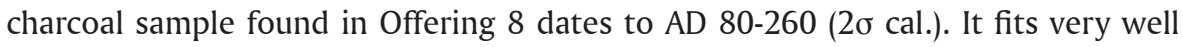
the dating established on the basis of ceramic material recovered inside Offering 8 .

However, archaeological materials from the ensuing Early Classic and Late Classic periods were scarcely found during excavations of Structure 99. This indicates that the two most important architectural periods in the case of Str. 99 were Protoclassic and Terminal Classic. Late Classic period most probably saw the construction of a new floor on top of the platform. Our research has also revealed that Structure W (long palace located south of Structure 99) was constructed in the Late or more probably, in the Terminal Classic period.

\section{Discussion}

To summarize, the following three important phases of Str. 99 were documented during archaeological research: i) Structure 99 Sub-1 was constructed in the final 
part of the Late Preclassic period and consisted of a wide building located on a low platform with a stairway on its southern side; ii) a large platform nearly $6 \mathrm{~m}$ high constructed during the final part of the Late Preclassic or Protoclassic; iii) three superstructures constructed on the summit of the platform during the final part of the Classic period. It must be noted that except for floors, no vestiges of Early or Late Classic architecture were detected during our research.

Of special interest are important vestiges of Protoclassic activity detected in Structure 99. Buildings and graves from this phase were also found in the Southern Sector of Nakum during research by the Nakum Archaeological Project as well as the Proyecto Triángulo of IDAEH. Archaeological data indicate that Nakum saw an important cultural and architectural resurgence during the Protoclassic phase. The huge Acropolis complex underwent an enormous rebuilding program at that time. Its platform was raised by $2-3 \mathrm{~m}$ and not long after, several new buildings including Structures 14, 15, E and D were built on this new level enclosing Patio 1. Further to the south, a large triadic pattern complex of the Central Acropolis was sealed by a new platform which was most probably plain at the top. Vestiges of Protoclassic phase were also found at the periphery of Nakum. Nevertheless, excavations of Structures 15 and 14 by the Nakum Archaeological Project should especially be considered in a Protoclassic context since a copious amount of excavated material can be dated to this phase. The first versions of both constructions (15 Sub- 1 and Sub-2 as well as 14 Sub-1, Sub-2 and Sub-3) were found to belong to the Protoclassic phase. Inside one of these early constructions a burial (no. 2) from the same period was also discovered. It was constructed within the platform of the first version of Structure 15 (15 Sub-1), and it belonged to a royal woman. The burial contained two Ixcanrio Orange Polychrome plates typical for the Protoclassic phase. Two radiocarbon samples found inside gave the following dates: $1790 \pm 35 \mathrm{BP}$ and $1715 \pm 30 \mathrm{BP}(2 \sigma$ cal A.D. 130-340 and A.D. 250-410, respectively).

The exact definition of the Protoclassic remains an unresolved issue. Archaeologist have defined it as a phase, complex, sub-complex, horizon or ceramic stage and use differing dates for it: 50 BC-AD 250 (Willey and Gifford, 1961), AD 1-300 (Gifford, 1976; Demarest and Sharer, 1982). Some scholars like Brady et al. (1998) propose a very long time span (ca. 500 years, from $75 \pm 25 \mathrm{BC}$ to AD $400 \pm 20$ ) for the Protoclassic; they define it as a ceramic stage and divide it into two parts (separated by the year $c a$. AD 150). Based on ceramic and glyphic inscriptions, Reese-Taylor, Walker and others (Reese-Taylor and Walker, 2002; Walker et al., 2006) have proposed a very late date for the Protoclassic: AD 159-238/292. Finally, there are scholars who argue that the term Protoclassic is misleading and its use should be eliminated; in its place they propose the application of such terms as Terminal Late Preclassic (Kosakowski, 2005) or Early Classic 1 (for its second part) (Walker et al., 2006).

The Late Preclassic-Early Classic transition is characterized by the socio-political crisis and collapse of various Maya sites, many of which were abandoned $c a$. the 
$2^{\text {nd }}$ century AD. Such situation was mainly documented in the Mirador Basin of northern Guatemala (Hansen, 2004; Walker et al., 2006: 719).

The growth of Nakum during the Protoclassic phase or period span contrasts with a prevailing lack of activity in the region. At Yaxha, excavations have revealed almost no Protoclassic structures. The same may be said of many other sites in the Triángulo Park area. Thus Nakum seems to be one of the most important settlements in this region during the discussed phase (Hermes, 1999; Źrałka et al., 2011). Accessible archaeological data indicate that Nakum might have experienced continuous growth during the Late Preclassic-Early Classic transition that was not disrupted by a drastic collapse.

Evidence of dense Terminal Classic occupation on the top of Structure 99 as well as in other parts of the North Group merits special attention. This reflects a situation similar to other parts of the site at that time. Research by the Triángulo Project carried out in the largest and most monumental sector of the site (the Southern Sector) recorded very copious evidence of Terminal Classic activity. At that time, Nakum experienced enormous demographic and political growth (Hermes, 2002; Źrałka et al., 2007; Źrałka, 2008; Źrałka and Hermes, 2012). One of the major aims of our recent research conducted at the lesser-known Northern Sector of the site was to check if this part of the site was likewise inhabited and if it had experienced any important building programs during the said period. One hypothesis stated that the large architectural surge recorded in the Southern Sector was at least partly provoked by the people who might have left the Northern Sector and move to the south. Archaeological work realized in Structure 99 showed that the two most important periods in the architectural history of this construction were the Protoclassic, followed by the Terminal Classic. During the latter period Structure 99 underwent important building programs, probably resulting in a change in its function. Three residential structures were built on its top. Moreover, the same period most probably saw the construction of Structure $\mathrm{W}-$ a long palace situated south of Structure 99. All archaeological data confirms important demographic growth in Nakum during the Terminal Classic. The data also indicate that during this period, previous constructions that had a religious function (such as Structure 99) were reused and adapted for new purposes, especially to create new habitation space.

The growth of Nakum during this turbulent period in Maya history is of special interest, since most Maya lowland centers at that time were experiencing a collapse and eventual abandonment. It seems that Nakum survived the collapse of other major cities such as Tikal or Naranjo by at least a century. As yet, there is no satisfactory answer as to why Nakum was thriving at the end of the Classic period, but it is possible that the socio-political crisis in the neighboring sites allowed Nakum's ruling elite to consolidate their power and gain control over local trade routes (including the one passing along the Holmul River). The large number of residential structures built or rebuilt during this time at Nakum may suggest a significant growth in the number of the local elites; this might have 
been the result of the influx of noble relatives from neighboring sites seeking shelter at Nakum. Nevertheless, the success of Nakum was rather brief, since by the end of the Terminal Classic period (ca. 950) the site was largely abandoned and it shared the fate of other lowland Maya centers.

\section{Acknowledgements}

The research at Nakum was made possible thanks to permission from the Ministry of Culture and Sports of Guatemala and the Institute of Anthropology and History of Guatemala (IDAEH). Funding was provided by the following institutions: the Ministry of Science and Higher Education of the Polish government (grants N109022-32/1234 and IP 2010-050670), the National Science Centre (grant 2011/03/B/ HS3/00686), the Foundation for the Advancement of Mesoamerican Studies Inc. (FAMSI; grant 06022), the Foundation for Polish Science (Exterius Programme grant), the Jagiellonian University, the Bratniak Foundation and Krakowskie Zakłady Automatyki S.A. We would also like to thank Samuel David for revising the English language of this text. 


\section{BIBLIOGRAPHY}

Brady, James E. and Pierre Robert Colas

2005 "Nikte Mo' Scattered Fire in the Cave of K'ab Chante': Epigraphic and Archaeological Evidence for Cave Desecration in Ancient Maya Warfare", Stone Houses and Earth Lords: Maya Religion in the Cave Context, pp. 149-166, Keith M. Prufer and James E. Brady (eds.). Boulder: University Press of Colorado.

Brady, James et al.

1998 “The Lowland Maya 'Protoclassic': A Reconsideration of its Nature and Significance”, Ancient Mesoamerica, 9: 17-38. Cambridge: Cambridge University Press.

Calderón, Zoila, Bernard Hermes, Breitner Gonzalez and Telma Tobar

2008 "La Acrópolis Interior de Nakum”, XXI Simposio de Investigaciones Arqueológicas en Guatemala, 2007, pp. 349-356, J. P. Laporte, B. Arroyo and H. Mejía (eds.). Guatemala: Museo Nacional de Arqueología y Etnología, Ministerio de Cultura y Deportes, Instituto de Antropología e Historia, Asociación Tikal and Fundación Arqueológica del Nuevo Mundo.

Crane, Eva

1999 The World History of Beekeeping and Honey Hunting. New York: Routledge.

Díaz del Castillo, Bernal

1968 Historia verdadera de la Conquista de la Nueva España. Madrid: Espasa-Calpe.

Farr, Olivia Navarro y Ana Lucía Arroyave

2007 "Un final macabro: La terminación ritual de la estructura M13-1 de El PerúWaka”, XX Simposio de Investigaciones Arqueológicas en Guatemala, 2006, pp. 699-719, J. P. Laporte, B. Arroyo and H. Mejía (eds.). Guatemala: Museo Nacional de Arqueología y Etnología (digital version).

Freidel, David A., Charles K. Suhler and Rafael Cobos Palma

1998 "Termination Ritual Deposits at Yaxuná: Detecting the Historical and Archaeological Contexts", The Sowing and the Dawning: Termination, Dedication and Transformation in the Archaeological and Ethnographic Record of Mesoamerica, pp. 135-144, Shirley B. Mock (ed.). Albuquerque: University of New Mexico Press.

Garber, James F.

1983 "Patterns of Jade Consumption and Disposal at Cerros, Northern Belize", American Antiquity, 48 (4): 800-807. Washington, D.C.: Society for American Archeology.

Guzmán, Miguel et al.

2011 Manejo de las abejas nativas sin aguijón en México: Melipona beecheii y Scaptotrigona mexicana, Manual técnico. México: Mutual. 
Hammond, Norman

1984 "Holmul and Nohmul: A Comparision and Assessment of two Maya Lowland Protoclassic Sites”, Cerámica de Cultura Maya, 13: 1-17. Philadelphia: Temple University.

Harrison, Peter D.

1999 The Lords of Tikal. New York and London: Thames and Hudson.

Harrison-Buck, Eleanor

2004 "Nourishing the Animus of Lived Space through Ritual Caching", K'axob: Ritual, Work, and Family in an Ancient Maya Village, pp. 65-85, Patricia McAnany (ed.). Los Angeles: Cotsen Institute of Archaeology and University of California (Monumenta Archeologica, 22).

Hellmuth, Nicholas

1975 "Nakum: A Late Classic Maya Ruin”, Archaeology, 28 (4): 270-272. New York: Archaeological Institute of America.

1978 Maya Archaeology. Tikal Copan Travel Guide: A Complete Guide to All of the Maya Ruins of Central America. Missouri: Foundation for Latin American Anthropological Research.

1992 A Report to IDAEH on Four Days Research at Nakum. Missouri: Foundation for Latin American Anthropological Research.

Helmke, Christophe

2006 "A Summary of the 1999-2002 Seasons of Archaeological Investigations at Pook's Hill, Cayo District, Belize", Research Reports in Belizean Archaeology, 3: 173-191. University Press of Florida.

Hermes, Bernard

1999 "La cerámica y otro tipo de evidencia anterior al periodo Clásico en Topoxte, Petén”, XII Simposio de Investigaciones Arqueológicas en Guatemala, 1998, pp. 1-49, J. P. Laporte and H. L. Escobedo (eds.). Guatemala: Museo Nacional de Arqueología y Etnología.

2002 "Síntesis preliminar de la ocupación prehispánica en el área central de Nakum", Beiträge Zur Allgemeinen und Vergleichenden Archäologie, 22: 277-285. Mainz: Verlag Philipp von Zabern.

Hermes, Bernard and Zoila Calderón

2003 "La secuencia de ocupación prehispánica en Nakum, Petén: una visión preliminar", XVI Simposio de Investigaciones Arqueológicas en Guatemala, 2002, pp. 305-319, J. P. Laporte, B. Arroyo, H. Escobedo and H. Mejía (eds.). Guatemala: Museo Nacional de Arqueología y Etnología.

Hermes, Bernard and Jarosław Źrałka

2008 "La ocupación del periodo Clásico Terminal en Nakum, Petén”, Antropología e Historia de Guatemala, III (7): 49-104. Guatemala: USAC.

Hermes, Bernard, Jarosław Źrałka and Zoila Calderón

2005 "Investigations on the Periphery of Nakum: New Data on the Complex Settle- 
ment of the Maya Site”, Mexicon, XXVII (6): 116-122. Munich: Verlag Anton Saurwein.

Inomata, Takeshi, Daniela Triadan and Otto Rodrigo Román

2010 "La transformación y continuidad de ritos durante el período Preclásico en Ceibal, Guatemala”, El ritual en el mundo maya: de lo privado a lo público, pp. 29-48, Andrés Ciudad Ruiz, Ma. Josefa Iglesias Ponce de León and Miguel Sorroche Cuerva (eds.). Madrid: Sociedad Española de Estudios Mayas and Universidad Nacional Autónoma de México (Publication 9).

Inomata, Takeshi et al.

2001 "In the Palace of the Fallen King: The Royal Residential Complex at Aguateca, Guatemala", Journal of Field Archaeology, 28 (3/4): 287-306. Leeds: Maney Publishing.

2002 "Domestic and Political Lives of Classic Maya Elites: The Excavation of Rapidly Abandoned Structures at Aguateca, Guatemala", Latin American Antiquity, 13 (3): 305-330. Washington, D.C: Society for American Archaeology.

McAnany, Patricia and Justin Ebersole

2004 "Ground and Polished Stone Tools", K'axob: Ritual, Work, and Family in an Ancient Maya Village, pp. 317-330, Patricia McAnany (ed.). Los Angeles: Cotsen Institute of Archaeology, University of California (Monumenta Archeologica, 22).

Mock, Shirley B.

1998 "Prelude", The Sowing and the Dawning Termination, Dedication, and Transformation in the Archaeological and Ethnographic Record of Mesoamerica, pp. 3-18, Shirley B. Mock (ed.). Albuquerque: University of New Mexico Press.

Mohar B., Luz María

1987 El tributo mexica en el siglo xVI: análisis de dos fuentes pictográficas. México: Centro de Investigaciones y Estudios Superiores en Antropología Social (Cuadernos de la Casa Chata, 154).

Moholy-Nagy, Hattula and William Coe

2008 "The Artifacts of Tikal: Ornamental and Ceremonial Artifacts and Unworked Material”, Tikal Report No. 27, Part A. Philadelphia: University of Pennsylvania Museum of Archaeology and Anthropology (University Museum Monograph, 127).

Morley, Sylvanus

1937-1938 The Inscriptions of Petén, vols. I-V. Washington: Carnegie Institution of Washington.

Narez, José

1988 "Algunos datos sobre las abejas y la miel en la época prehispánica”, Revista 
Mexicana de Estudios Antropológicos, XXXIV (1): 123-140. México: Sociedad Mexicana de Antropología.

Noriega, Raúl

1999 "Trabajos de restauración en el Templo A de Nakum, Petén”, XII Simposio de Investigaciones Arqueológicas en Guatemala, 1998, pp. 139-146, J. P. Laporte, H. Escobedo and A. C. Monzón de Suasnavar (eds.). Guatemala: Museo Nacional de Arqueología e Etnología, Ministerio de Cultura y Deportes, Instituto de Antropología e Historia de Guatemala and Asociación Tikal.

Noriega, Raúl and Bernard Hermes

2000 "Avance en los trabajos de investigación arqueológica y restauración en los Edificios N, 60 y 61 de Nakum”, XIII Simposio de Investigaciones Arqueológicas en Guatemala, 1999, pp. 419-438, J. P. Laporte, H. Escobedo and A. C. Monzón de Suasnavar (eds.). Guatemala: Museo Nacional de Arqueología y Etnología, Ministerio de Cultura y Deportes, IDAEH and Asociación Tikal.

Noriega, Raúl, Breitner González and Erwin Valiente

2008 "Procesos y resultados de las intervenciones de conservación en Nakum y el Edificio 218 de Yaxha”, XXI Simposio de Investigaciones Arqueológicas en Guatemala, 2007, pp. 275-282, J. P. Laporte, B. Arroyo and H. Mejía (eds.). Guatemala: Museo Nacional de Arqueología y Etnología.

Noriega, Raúl and Óscar Quintana

2002 "Programa de restauración: Proyecto Protección de Sitios Arqueológicos en Petén”, XV Simposio de Investigaciones Arqueológicas en Guatemala, 2001, pp. 228-238, J. P. Laporte, H. Escobedo and B. Arroyo (eds.). Guatemala: Museo Nacional de Arqueología y Etnología.

Pedroza Fuentes, Lisseth

2012 "Análisis de materiales de tres contextos subacuáticos: cenotes Kanun, Kanun Che'en, Kan Kab Che'en, Yucatán, México”, Dissertation in Archeology. México: Escuela Nacional de Antropología e Historia.

Perigny, Maurice de

1908 "Yucatán Inconnu", Journal de la Société des Américanistes de Paris, V: 67-84.

1911 "Les Ruines de Nakcum”, Journal de la Société des Américanistes de Paris, VIII: 5-22.

Ponciano, Erick M. and Alba Estela Pinto

2007 "Rito de terminación en la plaza principal de Aguateca: epílogo de su ocupación durante el siglo Ix”, XX Simposio de Investigaciones Arqueológicas en Guatemala, 2006, pp. 720-736, J. P. Laporte, B. Arroyo and H. Mejía (eds.). Guatemala: Museo Nacional de Arqueología y Etnología (digital version).

Pring, Duncan

1977 "Influence or Intrusion? The 'Protoclassic' in the Maya Lowlands", Social 
Process in Maya Prehistory: Studies in honour of Sir Eric Thompson, pp. 135-165, N. Hammond (ed.). London, New York and San Francisco: Academic Press.

2000 The Protoclassic in the Maya Lowlands, Oxford: Archeopress (British Archaeological Reports International Series 908).

Quintana, Óscar and Wolfgang Wurster

2002 "Un nuevo plano del sitio maya de Nakum, Petén, Guatemala", Beiträge Zur Allgemeinen und Vergleichenden Archäologie, 22: 243-275. Mainz: Verlag Philipp von Zabern.

Reese-Taylor, Kathryn and Debra Walker

2002 "The Passage of the Late Preclassic into the Early Classic", Ancient Maya Political Economies, pp. 87-122, Marilyn Masson and David Freidel (eds.). New York: Altamira Press.

Schieber de Lavarreda, Christa

2002 "La ofrenda de Abaj Takalik", XV Simposio de Investigaciones Arqueológicas en Guatemala, 2001, pp. 459-473, J. P. Laporte, H. Escobedo and B. Arroyo (eds.). Guatemala: Museo Nacional de Arqueología y Etnología.

Sotelo Santos, Laura Elena

2002 "Los dioses antropomorfos del Códice Madrid. Aproximación a las representaciones antropomorfas de un libro sagrado maya". Ph. D. dissertation in Mesoamerican Studies. México: Universidad Nacional Autónoma de México, Programa de Maestría y Doctorado en Estudios Mesoamericanos, Facultad de Filosofía y Letras and Instituto de Investigaciones Filológicas.

Stanton, Travis W., M. Kathryn Brown and Jonathan B. Pagliaro

2008 "Garbage of the Gods? Squatters, Refuse Disposal, and Termination Rituals among the Ancient Maya”, Latin American Antiquity, 19 (3): 227-247. Washington, D.C.: Society for American Archaeology.

Stone, Andrea and Marc Zender

2011 Reading Maya Art: A Hieroglyphic Guide to Ancient Maya Painting and Sculpture. London: Thames and Hudson.

Straight, Kirk D. and Damien B. Marken

2006 "Los depósitos de terminación del Templo XIX, Palenque, Chiapas", XIX Simposio de Investigaciones Arqueológicas en Guatemala, 2005, pp. 441-449, J. P. Laporte, B. Arroyo and H. Mejía (eds.). Guatemala: Museo Nacional de Arqueología y Etnología (digital version).

Stross, Brian

1998 "Seven Ingredients in Mesoamerican Ensoulment: Dedication and Termination in Tenejapa", The Sowing and the Dawning: Termination, Dedication and Transformation in the Archaeological and Ethnographic Record of Mesoamerica, pp. 31-40, Shirley B. Mock (ed.). Albuquerque: University of New Mexico Press. 
Taube, Karl

2004 Olmec Art at Dumbarton Oaks. Washington: Trustees for Harvard University (Dumbarton Oaks Research Library and Collection).

Tozzer, Alfred

1913 A Preliminary Study of the Prehistoric Ruins of Nakum, Guatemala. Cambridge: Peabody Museum of Archaeology and Ethnology and Harvard University (Memoirs of the Peabody Museum of Archaeology and Ethnology, V/3).

Valdés, Juan Antonio and Federico Fahsen

2004 "Disaster in Sight: The Terminal Classic at Tikal and Uaxactún”, The Terminal Classic in the Maya Lowlands: Collapse, Transition, and Transformation, pp. 140161, A. Demarest, P. Rice and D. Rice (eds.). Boulder: University Press of Colorado.

Vidal Lorenzo, Cristina and Juan Antonio Valdés

2007 "La huella arqueológica del abandono de los palacios de La Blanca", La Blanca y su entorno, pp. 11-20. Cristina Vidal Lorenzo and Gaspar Muñoz Cosme (eds.). Valencia: Ediciones UPV (Cuadernos de arquitectura y arqueología maya).

Wagner, Elizabeth

2002 "White Earth Bundles-The Symbolic Sealing and Burial of Buildings among the Ancient Maya", Jaws of the Underworld: Life, Death, and Rebirth among the Ancient Maya, pp. 55-69, Pierre R. Colas, Geneviève LeFort, and Bodil Liljefors Persson (eds.). Munich: Verlag Anton Saurwein (Acta Mesoamericana 16).

Walker, Debra S., Kathryn Reese-Taylor and Peter Mathews

2006 "Después de la caída: Una redefinición del Clásico Temprano Maya”, XIX Simposio de Investigaciones Arqueológicas en Guatemala, 2005, pp. 715-728, J. P. Laporte, B. Arroyo and H. Mejía (eds.). Guatemala: Museo Nacional de Arqueología y Etnología (versión digital).

Willey, Gordon and James Gifford

1961 "Pottery of the Holmul Style I from Barton Ramie, British Honduras", Essays in Pre-Columbian Art and Archaeology, pp. 152-170, Samuel Lothrop (ed.). Cambridge: Harvard University Press.

Źrałka, Jarosław

2008 Terminal Classic Occupation in the Maya Sites located in the Area of Triángulo Park, Petén, Guatemala. Cracow: Jagiellonian University Press (Prace Archeologiczne, 62).

Źrałka, Jarosław and Bernard Hermes

2012 "Great Development in a Troubled Times: Terminal Classic at Nakum, Petén, Guatemala”, Ancient Mesoamerica, 23: 161-187. Cambridge University Press. 
Źrałka, Jarosław et al.

2011 "La ocupación de Nakum entre los años 100 a.C. y 450 d.C.: ¿Chicanel, Floral Park, Tzakol o un momento de transición?”, XXV Simposio de Investigaciones Arqueológicas en Guatemala, 2010, pp. 13-34, B. Arroyo, L. Paiz Aragón, A. Linares Palma and A. Arroyave (eds.). Guatemala: Museo Nacional de Antropología e Historia. 
